Reading Palestine 
THIS PAGE INTENTIONALLY LEFT BLANK 


\title{
Reading Palestine
}

\author{
Printing and Literacy, \\ I900-I948
}

$\Longleftarrow$

Ami Ayalon

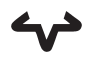

U N I V E R S I T Y

O F TEXAS PRES

A U S T I N 
Copyright $(92004$ by the University of Texas Press

All rights reserved

Printed in the United States of America

First edition, 2004

Requests for permission to reproduce material from this work should be sent to Permissions, University of Texas Press, P.O. Box 7819,

Austin, TX 78713-7819.

(2) The paper used in this book meets the minimum requirements of ANSI/NISO Z39.48-I992 (RI997) (Permanence of Paper).

Library of Congress Cataloging-in-Publication Data

Ayalon, Ami.

Reading Palestine : printing and literacy, 1900-1948 / Ami Ayalon.— Ist ed.

p. $\mathrm{cm}$.

Includes bibliographical references and index.

ISBN 0-292-70579-4 (cloth : alk. paper) — ISBN 0-292-70593-X (pbk. : alk. paper)

I. Reading-Palestine-History-2oth century. 2. Literacy-Palestine-History2oth century. I. Title.

LBIO5O.A93 2004

$302.2^{\prime} 244^{\prime} 094694-\mathrm{dc} 22$

2004005733 
$\Longleftarrow$

To Bernard Lewis

And to the memory of Charles Issawi

Two masters, two friends 